\title{
Confirmation of Tuntun Angin (Elaeocarpus floribundus) Taxonomic Status Using matK and ITS Sequences
}

\author{
${ }^{\square}$ Dewi Indriyani Roslim, Siti Khumairoh, Herman
}

DOI: 10.15294/biosaintifika.v8i3.7406

Laboratory of Genetics, Department of Biology, Faculty of Mathematics and Natural Sciences, Universitas Riau, Indonesia

\section{History Article}

Received 6 October 2016 Approved 26 November 2016 Published 24 December 2016

\section{Keywords:}

Elaeocarpus floribundus; ITS; Kajuik Lake; matK; tuntun angin

\begin{abstract}
Tuntun angin is one of important floodplain plants in and around Kajuik Lake located in Riau Province, Indonesia. Morphological identification shows that the scientific name of this plant is Elaeocarpus floribundus. The study aimed to confirm the taxonomic status of tuntun angin using mat $K$ and nuclear intergenic spacer (ITS) sequences. The methods included fresh leaf DNA isolation, polymerase chain reaction, electrophoresis, sequencing, and data analysis using BLASTn program and MEGA software version 6.06 programs. The results showed that the matK sequence (519 bp) of tuntun angin had highest similarity to $E$. floribundus mat $K$ sequence that was available in GenBank. It was supported by the high max score (937), low Evalue $(0.0)$, high identity value $(100 \%)$, and high query cover $(100 \%)$. However, the ITS sequence of tuntun angin did not show similarity to $E$. floribundus ITS sequence because there was no database of the sequence in GenBank. This study was able to confirm the taxonomic status of tuntun angin as E. floribundus using mat $K$ sequence and also showed that morphological and molecular identification techniques were complementary to each other. Moreover, this study enriched the DNA sequence database of E. floribundus in GenBank which will be useful for this species' molecular identification.
\end{abstract}

\section{How to Cite}

Roslim, D. I., Khumairoh, S. \& Herman, H. (2016). Confirmation of Tuntun Angin (Elaeocarpus floribundus) Taxonomic Status Using matK and ITS Sequences. Biosaintifika: Journal of Biology \& Biology Education, 8(3), 392-399.

(C) 2016 Universitas Negeri Semarang
Correspondence Author:

J1. HR Soebrantas, Panam, Pekanbaru 28293, Riau

E-mail: dewiindriyaniroslim@gmail.com
p-ISSN 2085-191X

e-ISSN 2338-7610 


\section{INTRODUCTION}

Riau Province has many floodplain ecosystems which contain genetic diversity of the endemic flora and fauna. Kajuik Lake is part of the floodplain ecosystem of Kampar River located in Langgam, Pelalawan Regency, Riau Province, Indonesia. Various plants - suggested endemic to Riau - grow in Kajuik Lake, such as rattan (Calamus sp), renghas (Gluta sp), pandan (Pandanus $\mathrm{sp}$ ), durik-durik (Syzygium sp), and tuntun angin (Elaeocarpus floribundus) (Elvyra \& Yus, 2012; Roslim, 2016; Roslim et al., 2016a).

Such plants play important roles in maintaining the quality and the quantity of river water, resisting erosion, supplying nutrient for fish and other animals in river, and providing sites of spawning and nursery for fish. Fish migrates from the river body to the floodplain lake when the water in river overflows in rainy season (Zeug \& Winemiler, 2008). The fish look for roots or other parts of plant which are submerged to put their eggs and hide from predators (Pease et al., 2006). One of fish that migrated to Kajuik Lake is selais fish which is a Riau endemic fish (Elvyra \& Yus, 2012). Not only fish, others animals like birds, crabs, shrimps, and insects also live in floodplain ecosystem (Banner \& MacKenzie, 1998; Price \& Lovett, 2002).

Tuntun angin grows in and around Kajuik Lake has been identified as Elaeocarpus floribundus based on morphological characters (Elvyra \& Yus, 2012). It is a kind of tree that can grow in tropical floodplain forest (Brahma et al., 2013; Rahman \& Vacik, 2015) and a member of Elaeocarpaceae. The fruit and the leaf of this plant are rich in vitamin and antioxidant which are useful for treatments of various diseases (Khomdram et al., 2014; Rahman \& Vacik, 2015). Sitakunda people in India use this plant as medicine, fodder, and firewood (Rahman \& Vacik, 2015). E. floribundus could be found among others in Pangandaran, Jawa Barat, Indonesia (Rosleine \& Suzuki, 2012), Manipur, India (Khomdram et al., 2014), and Singapore (Erickson et al., 2014).

Before DNA barcoding technique developed rapidly, plant characterization and identification process was commonly conducted based on morphological characters (Cheong \& RanghooSanmukhiya, 2013; Snow et al., 2016; Roslim et al., 2016b) because they were easier and cheaper. Nevertheless, not all plant species can be characterized and or identified based on morphological characters due to some characters which the ex- pression depends on the environment and or the plant developmental stage. In addition, complete organ and non damaged organ are difficult to obtain. Moreover, the morphological identification requires an expertise in taxonomy. Scientists overcome those problems by developing molecular identification technique using short DNA sequence of an organism genome, and this technique is called DNA barcoding (Hebert et al., 2003). The advantage of DNA barcoding technique is rapid and being able to identify the plant species that is morphologically indistinguishable and or wether an organ under study is incomplete or damage. Besides that, molecular identification can be performed by everyone even if she or he is not a taxonomist (Hebert et al., 2003).

Some short DNA sequences have been developed as DNA barcode for the plant molecular identification, such as sequences of $r b c L, m a t K$, ITS, and psbA-trnH intergenic spacer (White et al., 1990; Kress et al., 2005; Lahaye et al., 2008; CBOL Plant Working Group, 2009; Ali et al., 2014; Patwardhan et al., 2014). This paper reports the use of two DNA barcodes, namely mat $K$ and ITS, because the plant molecular identification should be done using a combination of DNA barcodes (Kress et al., 2005; Kress \& Erickson, 2007; Pang et al., 2012; Castro et al., 2015). It is not like the animal molecular identification that can be performed only by using single DNA barcode namely COI which is located in animal mithocondrial genome (Hebert et al., 20013; Kurniawaty et al., 2016).

The mat $K$ sequence, together with $r b c L$ sequence, has been confirmed and standardized as the universal DNA barcodes for plants (CBOL Plant Working Group, 2009). The matK is a gene encoding maturaseK enzyme and positioning in plant chloroplast genome. This gene undergoes high mutation and rapid evolution so that it will be less conservative compared to $r b c L$ gene, and also this gene has the capability to differentiate some species in Agiosperm (Lahaye et al., 2008; Patwardhan et al., 2014). While, the ITS is a region in plant nuclear genome located in between the genes encoding RNA ribosomal, such as $18 \mathrm{~S}$, $5.8 \mathrm{~S}$, and 26S. The number of ITS in plant nuclear genome is abundant and the universal primer is available. This region is often used in plant molecular identification at interspecies and intraspecies levels (White et al., 1990; 2004; Kress et al., 2005; Ali et al., 2014). Therefore, both sequences are used in this study to confirm and identify the taxonomic status of tuntun angin. 


\section{METHODS}

The plant materials used in this study were parts of tuntun angin tree such as leaf, branch, and flower that were collected from Kajuik Lake, Langgam District, Pelalawan Regency, Riau Province, Indonesia. Primers were designed based on sequences of mat $K$ and ITS of Elaeocarpus floribundus (GI: 672917561) available in GenBank, such as matK_Ef_F: 5'-TAC GAT CAA CAT CCT CTC GG-3' (forward), matK_Ef_R: 3'-GTG TAC AAA TCG GTC GAT AA-5'(reverse), ITS_Ef_F: 5'- CAG AAA CGA CCC GTG AAC-3', dan ITS_Ef_R: 5'- CAT CGA GGT CTT TGG ATC A-3'.

Field observation was performed to characterize the morphological characters of tuntun angin. The observation was referred to Tjitrosoepomo (2003), Oyen (2011), Uddin (2014), and Fern (2014).

The fresh leaves were used to extract total DNA using DNeasy plant mini kit with the procedure according to manufacturing instruction (Qiagen). The quality and the quantity of total DNA were predicted using electrophoresis on $1.2 \%$ agarose gel in $1 \mathrm{X}$ TBE buffer (Tris-BorateEDTA pH 8.0) at 65 volt for 30 minutes.

A primer pairs of matK_Ef_F/matK_ Ef_R was used to amplify mat $K$ sequence and ITS_Ef_F/ITS_Ef_R to amplify ITS sequence. Amplification was carried out in a reaction volume $50 \mu$ containing $1 \mathrm{X}$ buffer PCR (plus $\mathrm{Mg}^{2+}$ ) (Thermo Scientific), $0.1 \mathrm{mM}$ dNTPs (Thermo Scientific), $2.4 \mu \mathrm{M}$ forward primer, $2.4 \mu \mathrm{M}$ reverse primer, 2 U Dream Taq DNA polymerase (Thermo Scientific), and $1 \mathrm{ng}$ total DNA, and aquabidestilata (Porebski et al., 1997). The PCR conditions were as follows: pre-PCR at $95^{\circ} \mathrm{C}$ for 5 minutes followed by 35 cycles consisting of denaturation at $95^{\circ} \mathrm{C}$ for 45 seconds, primer annealing for 45 seconds at $47^{\circ} \mathrm{C}$ for ITS primer pair and $48^{\circ} \mathrm{C}$ for mat $\mathrm{K}$ primer pair, and primer elongation or extension at $72^{\circ} \mathrm{C}$ for 1 minute 30 seconds. After that, post PCR was performed at $72^{\circ} \mathrm{C}$ for 10 minutes.

The PCR products were then migrated on $1.2 \%$ agarose gel in $1 \mathrm{X}$ TBE buffer, at 65 volt for one hour. The gel was then stained with $5 \mu \mathrm{g} / \mathrm{ml}$ of ethidium bromide, visualized on UV lamp ( $\mathrm{Wi}$ seUv WUV-M20, Daihan Scientific), and recorded.

The PCR products were then sent to PT Genetika Science Indonesia in Jakarta to be purified and sequenced at $1^{\text {st }}$ Base Malaysia. The DNA sequencing is a technique to determine the order of nucleotides precisely within a DNA molecule and the sequencing was performed in two direction using PCR primers.

The DNA sequences were then analyzed and aligned using BLASTn (Basic Local Alignment Search Tool) (Altschul et al., 1997) and MEGA software versi 6.06 .

\section{RESULTS AND DISCUSSION}

\section{Tuntun angin description}

Tuntun angin is an annual tree and has brown hard lignosus wood with grey spots. Tree height is about 14-16 meter and can reach 49 meter. The stem is round with rough surface. The green leaves are arranged spirally, $3-5 \mathrm{~cm}$ in size, ovalis or ellipticus, acuminate tip, obtusus leaf base, and serrated leaf edges. The leaf vein is pinnate. The branches are monopodial. The white colour flowers form inflorescentia racemus with the bowl-like base and the triangular narrow sepals. The stamens are more than 20. Ovarium is superior. The flower is $5-7.5 \mathrm{~cm}$ long. The flower is bisexual, i.e. the stamen and the pistile are in a flower.The fruit is $2.5-3.2 \mathrm{~cm}$ in size, drupe in shape, narrowed at the base, bluntly pointed at the apex, light green in young fruit, and yellowish green in mature fruit. The flesh of fruit is acidic (Figure 1 and Figure 2).

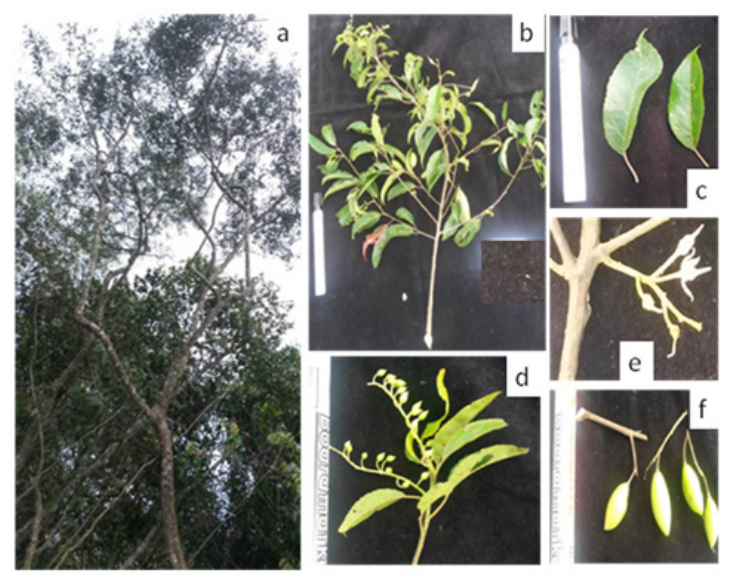

Figure 1. Samples of tuntun angin that were collected from Kajuik Lake. (a) the tree is 14 meter in height, (b) branches, (c) leaves, (d) branches with leaves and unbloom flowers, (e) bloom flowers, and (f) fruits.

Local people around Kajuik Lake use the fruit as bait for fishing. The extract of the fruits is good for skin and used as an anti-aging herb (Oyen, 2011). The leaves are used to treat rheumatic, dysentry, and diarrhea diseases, while an infusion of the bark and leaves is used as a mouthwash (Uddin, 2014). 


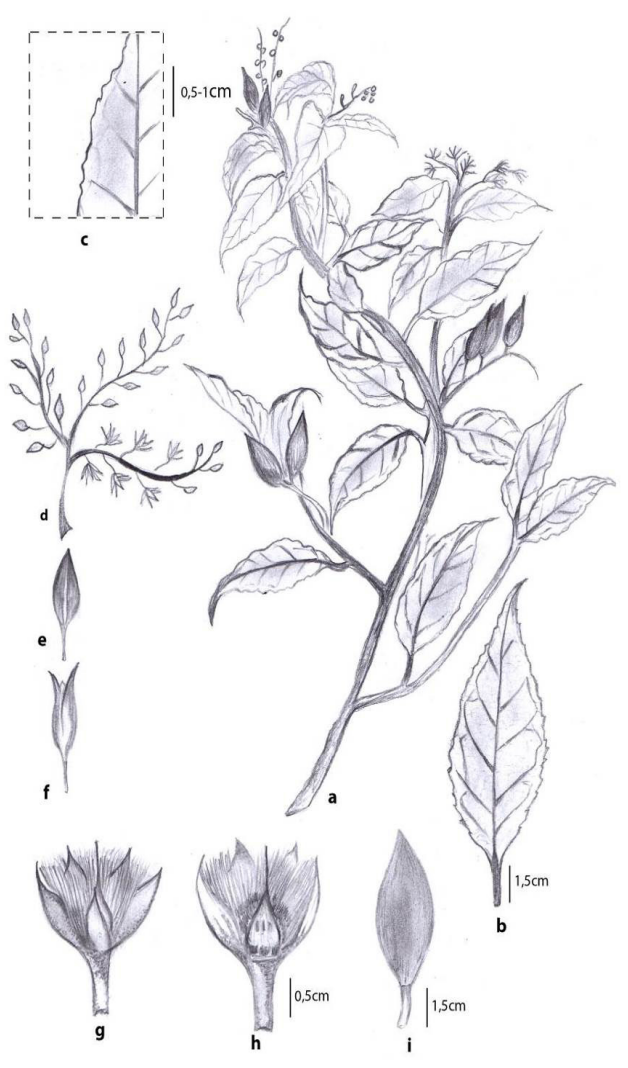

Figure 2. Sketch of parts of tuntun angin plant. (a) branch, (b) the toothed margins leaf, (c) a piece of leaf, (d) inflorescentia racemus, (e) unbloom flower, (f) bloom flower, (g) bloom flower perfectly, (h) inside view of flower, (i) fruit or drupe.

\section{Total DNA molecules and DNA fragment of matK and ITS}

The total DNA molecules obtained in this study were intact, not smeared, and enough for PCR requirement. The PCR products of matK and ITS fragments (Figure 3) were thick enough for sequencing requirement. The thick and single band of PCR products will produce good sequences (Nugraha et al., 2014; Roslim et al., 2016a; Roslim, 2016).

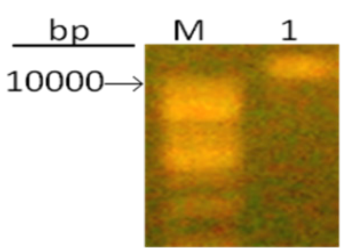

(a)

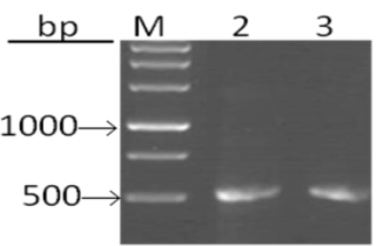

(b)
Figure 3. Profile of the total DNA (a) and PCR products (b) of tuntun angin. (M) $1 \mathrm{~kb}$ DNA Ladder, (1) the total DNA and the DNA fragment of (2) $m a t K$ and (3) ITS.

\section{Analysis of matK and ITS sequences of tuntun angin}

The mat $K$ sequence obtained in this study is 519 bp in size (GenBank accession number: KX365743) while ITS region 438 bp (GenBank accession number: KX365744) (Figure 4). Alignment analysis of both sequences using BLASTn showed that the mat $K$ sequence of tuntun angin was $100 \%$ similar to $m a t K$ sequence of $E$. floribundus availabled in GenBank database (Table 1). However, the ITS sequence of tuntun angin was not similar to ITS sequence of E. floribundus because there was no database of the sequence in GenBank.

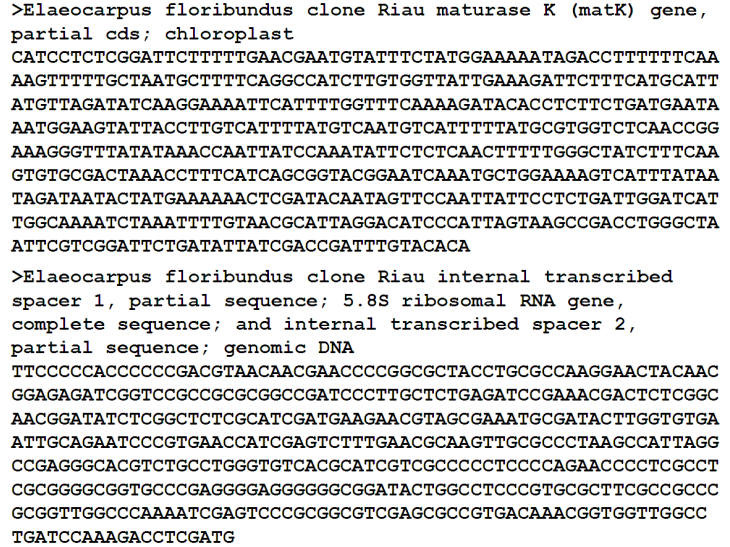
TGATCCAAAGACCTCGATG

Figure 4. Sequence of matK (upper) and ITS (lower) of tuntun angin.

This study showed that the determination of a plant species' name using the molecular identification technique must consider some BLAST parameters, for example, high max score, high total score, high query cover, low E-value (0.0), and 100\% identity (Madden, 2013; Roslim, 2016; Roslim et al., 2016a). If the identity value does not reach $100 \%$, then the species' name or taxonomic status of sample observed can not be determined. In addition, this study also showed that the molecular identification technique should be supported by the availability and the abundance of DNA sequences database (Will \& Rubinoff, 2004; DeSalle, 2006; Hajibabaei et al., 2007; Roslim, 2016), due to the fact that DNA sequence of organism identified must be aligned and compared to the DNA sequence database which was generated from known species (Hajibabaei et al., 2007). Until now (updated in October $1^{\text {st }}, 2016$ ), the DNA sequences database of Elaeocarpus which are available in GenBank have been very abundant, i.e. 12406 data. The number of $E$. floribundus DNA sequences is 5 data which include $r b c L$ (3 data) and matK (2 data).

The mat $K$ gene is a gene with high varia- 
Table 1. BLASTn analysis of mat $K$ sequence of tuntun angin.

\begin{tabular}{lcccccc}
\hline Description & $\begin{array}{c}\text { Max } \\
\text { score }\end{array}$ & $\begin{array}{c}\text { Total } \\
\text { score }\end{array}$ & $\begin{array}{c}\text { Query } \\
\text { cover (\%) }\end{array}$ & $\begin{array}{c}\text { E } \\
\text { value }\end{array}$ & $\begin{array}{c}\text { Ident } \\
(\%)\end{array}$ & Accession \\
\hline $\begin{array}{l}\text { Elaeocarpus floribundus voucher } \\
\text { BT_0095962077 maturase K (matK) gene, } \\
\text { partial cds; chloroplast }\end{array}$ & 937 & 937 & 100 & 0.0 & 100 & KJ708917.1 \\
$\begin{array}{l}\text { Elaeocarpus glabripetalus isolate BB0910 } \\
\text { maturase K (matK) gene, partial cds; } \\
\text { chloroplast }\end{array}$ & 922 & 922 & 100 & 0.0 & 99 & KR530764.1 \\
$\begin{array}{l}\text { Elaeocarpus decipiens isolate SCBGP542_1 } \\
\text { maturase K (matK) gene, partial cds; } \\
\text { chloroplast }\end{array}$ & 922 & 922 & 100 & 0.0 & 99 & KP094138.1 \\
$\begin{array}{l}\text { Elaeocarpus duclouxii isolate SCBGP451_1 } \\
\text { maturase K (matK) gene, partial cds; } \\
\text { chloroplast }\end{array}$ & 922 & 922 & 100 & 0.0 & 99 & KP094019.1 \\
$\begin{array}{l}\text { Elaeocarpus sylvestris isolate SCBGP255_1 } \\
\text { maturase K (matK) gene, partial cds; } \\
\text { chloroplast }\end{array}$ & 922 & 922 & 100 & 0.0 & 99 & KP093686.1 \\
\hline
\end{tabular}

Table 2. The distance matrix between tuntun angin from Kajuik Lake and some species in genus Elaeocarpus based on matK sequence.

\begin{tabular}{lcccccccc}
\hline Accession & 1 & 2 & 3 & 4 & 5 & 6 & 7 & 8 \\
\hline 1. Tuntun Angin & - & & & & & & & \\
2. E. floribundus & 0.000 & - & & & & & & \\
3. E. decipiens & 0.004 & 0.004 & - & & & & & \\
4. E. duclouxii & 0.004 & 0.004 & 0.000 & - & & & & \\
5. E. austroyunnanensis & 0.006 & 0.006 & 0.002 & 0.002 & - & & & \\
6. E. glabripetalus & 0.004 & 0.004 & 0.000 & 0.000 & 0.002 & - & & \\
7. E. prunifolioides & 0.009 & 0.009 & 0.013 & 0.013 & 0.015 & 0.013 & - & \\
8. E. sphaerocarpus & 0.009 & 0.009 & 0.013 & 0.013 & 0.015 & 0.013 & 0.009 & - \\
\hline
\end{tabular}

tion compared to others in a plant chloroplast genome and can be used for identification and verification of plant species. The mat $K$ gene encodes maturase-like protein that helps splicing its own and other genes in chloroplast (Lambowitz \& Zimmerly, 2004; Zoschke et al., 2010). The matK gene had been used for molecular identification and phylogenetic analysis of legum (Legumenusae) (Wojciechowski et al., 2004), angiosperm (Yu et al., 2011), and some spesies in genus Vicia (Raveendar et al., 2015). In this study, the use of $m a t K$ as DNA barcode proved to be able to verify the taxonomic status of tuntun angin which has previously been identified morphologically as $E$. floribundus by Elvyra \& Yus (2012) at Universitas Andalas (UNAND), Padang.

This verification is helpful to improve public knowledge that the matK sequence could indeed be used for plant molecular identification. The advantages of the plant molecular identifi- cation using DNA barcoding technique are as follows: (1) the plant molecular identification could be performed by anyone, either taxonomist or non taxonomist; (2) unlike identification using morphological characters, the DNA sequence or the DNA barcode is not influenced by the environment; and (3) the molecular identification is easy and fast if the DNA sequence database of target species is provided. Until now, the ITS database of E. floribundus in GenBank has not been available. Therefore, this research has a novelty, i.e. enhanced the DNA sequence database of $E$. floribundus in public database.

Similar research has been conducted by Kolondam et al. (2012) to confirm the taxonomic status of payus limondok orchid (Phaius tancarvilleae) using DNA barcode of $r b c L$ and matK. The result showed that mat $K$ sequence is more capable to be a DNA barcode for payus limondok orchid than $r b c L$ sequence. Bangol et al. (2014) also 
reported the potency of mat $K$ sequence as DNA barcode for pangi plant (Pangium edule).

\section{Phylogenetic analysis}

The DNA sequences of tuntun angin and some species in genus Elaeocarpus were then converted into distance matrix (Table 2) and dendrogram (Figure 5) and they will describe similarity or relationship between accessions. The farther the genetic distance between accessions showed the differences of a large number of nucleotide and far relationship between the two.

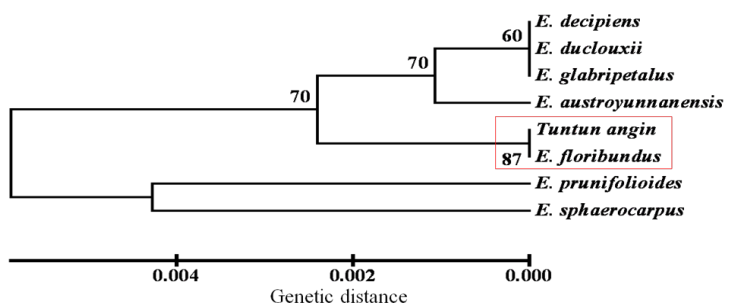

Figure 5. Phylogenetic tree between tuntun angin and some species in genus Elaeocarpus based on mat $K$ sequence using UPGMA method with 1000 bootsrap.

The genetic distance between tuntun angin and E. floribundus was 0.0 and it means that they are very similar based on the mat $K$ sequence. They were also very similar based on morphological characters. Furthermore, phylogenetic analysis showed that tuntun angin was clustered in one group and had closer relationship with $E$. floribundus rather than others. This result was in accordance with the BLASTn analysis results and it strengthens the taxonomic status of tuntun angin as E. floribundus.

Since the first time it was developed, the DNA barcode aimed to help species identification using standardized short DNA sequence with minimum length which was deposited in major public database, such as the National Center for Biotechnology Information's GenBank (NCBI, GenBank), the European Molecular Biology Laboratory (EMBL), and the Barcode of Life Data System, and had other corroborating data about the species. Today, the existence of the DNA barcode in public database has made a possibility for some people to acces the Linnaean taxonomic system, like conservationists, agencies deal with control of pests, food safety, and invasive species, geneticists, etc. (Hebert \& Gregory, 2005). The universal and standardized DNA barcodes for plant molecular identification are $r b c L$ and matK (CBOL Plant Working Group, 2009), while ITS region is the alternative DNA sequence (Bolson et al., 2015). Inspite of the combinati- on of DNA barcodes, also the plant molecular identification must be complemented or combined to other information about the species identified, for examples, morphological characters, developmental stages, and ecology (Smith et al., 2005). It because, morphological and molecular identification techniques were complementary to each other and the morphological identification technique cannot be subtituted by molecular identification technique (Will \& Rubinoff, 2004). Furthermore, domain of taxonomy is the discovery of species and domain of DNA barcoding is identification of species which depends on established taxonomy. Therefore, molecular identification technique still needs other corroborating data (DeSalle, 2006).

\section{CONCLUSION}

This study was able to confirm the taxonomic status of tuntun angin as E. floribundus using mat $K$ sequence and to enrich database of E. floribundus ITS sequence in GenBank. The success to confirm the taxonomic status of tuntun angin was supported by the availibility of matK sequence of E. floribundus in GenBank. In addition, morphological and molecular identification techniques were complementary to each other. Further experiments to enrich the DNA sequence database of E. floribundus therefore it supports the plant molecular identification is recommended.

\section{ACKNOWLEDGMENTS}

This study was supported by Dr. Dewi Indriyani Roslim via DIPA Universitas Riau 2016 for 'Penelitian Unggulan Universitas Riau' project

\section{REFERENCES}

Ali, M. A., Gyulai, G., Hidvegi, N., Kerti, B., Al Hemaid, F. M., Pandey, A. K., \& Lee, J. (2014). The changing epitome of species identification-DNA barcoding. Saudi journal of biological sciences, 21(3), 204-231.

Altschul, S. F., Madden, T. L., Schäffer, A. A., Zhang, J., Zhang, Z., Miller, W., \& Lipman, D. J. (1997). Gapped BLAST and PSI-BLAST: a new generation of protein database search programs. Nucleic acids research, 25(17), 3389-3402.

Bangol, I., Momuata, L. I., \& Kumaunang, M. (2014). Barcode DNA tumbuhan pangi (Pangium edule $R$.) berdasarkan gen matK. Jurnal MIPA Unsrat Online, 3(2), 113-119.

Banner, A. \& MacKenzie, W. (1998). Riparian Areas: Providing Landscape Habitat Diversity, Part 5 of 7. 
Extension Note. Ministry of Forests Research Program, British Columbia.

Bolson, M., Smidt, EdC., Brotto, M. L., \& SilvaPereira, V. (2015). ITS and trnH-psbA as efficient DNA barcodes to identify threatened commercial woody Angiosperms from Southern Brazilian Atlantic rainforests. PLoS ONE, 10(12), e0143049.

Brahma, S., Narzary, H., \& Basumatary, S. (2013). Wild edible fruits of Kokrajhar district of Assam, North-East India. Asian Journal of Plant Science and Research, 3(6), 95-100.

Castro, C., Hernandez, A., Alvarado, L., \& Flores, D. (2015). DNA Barcodes in Fig Cultivars (Ficus carica L.) Using ITS Regions of Ribosomal DNA, the psbA-trnH Spacer and the matK Coding Sequence. American Journal of Plant Sciences, 6(01), 95.-102.

Cheong, M. L. S. \& Ranghoo-Sanmukhiya, V. M. (2013). Phylogeny of Syzygium species using morphological, RAPD and ISSR Markers. International Journal of Agriculture \& Biology, 15(3), 511-516.

DeSalle, R. (2006). Species discovery versus species identification in DNA barcoding efforts: response to Rubinoff. Conservation Biology, 20(5), 1545-1547.

Elvyra, R. \& Yus, Y. (2012). Ikan Lais dan Sungai Paparan Banjir di Provinsi Riau. Pekanbaru: UR Press Pekanbaru.

Erickson, D. L., Jones, F. A., Swenson, N. G., Pei, N., Bourg, N. A., Chen, W., Davies, S. J., Ge, X. J., Hao, Z., Howe, R. W. \& Huang, C. L. (2014). Comparative evolutionary diversity and phylogenetic structure across multiple forest dynamics plots: a mega-phylogeny approach. Frontiers in genetics, 5, 358 .

Fern, K. (2014). Elaeocarpus floribundus. Useful tropical plants database. http://tropical. theferns.info/ query.php. [7 Nov 2015].

Group, C. P. W., Hollingsworth, P. M., Forrest, L. L., Spouge, J. L., Hajibabaei, M., Ratnasingham, S., van der Bank, M., Chase, M. W., Cowan, R. S., Erickson, D. L. \& Fazekas, A. J. (2009). A DNA barcode for land plants. Proceedings of the National Academy of Sciences, 106(31), 1279412797.

Hajibabaei, M., Singer, G. A. C., Hebert, P. D. N., \& Hickey, D. A. (2007). DNA barcoding: how it complements taxonomy, molecular phylogenetics and population genetics. TRENDS in Genetics, 23(4), 167-172.

Hebert, P. D., Cywinska, A., \& Ball, S. L. (2003). Biological identifications through DNA barcodes. Proceedings of the Royal Society of London B: Biological Sciences, 270(1512), 313-321.

Hebert, P. D. N. \& Gregory, T. R. (2005). The Promise of DNA Barcoding for Taxonomy. Systematic biology, 54(5), 852-859.

Khomdram, S., Barthakur, S., \& Devi, G. S. (2014). Biochemical and Molecular Analysis of Wild Endemic Fruits of the Manipur Region of In- dia. International Journal of Fruit Science, 14(3), 253-266.

Kolondam, B. J., Lengkong, E., Polii-Mandan, J., Pinaria, A., \& Runtunuwu, S. (2012). DNA barcode of payus limondok orchid (Phaius tancarvilleae) based on the rbcL and matK genes. Jurnal Bioslogos, 2(2), 55-62.

Kress, W. J., Wurdack, K. J., Zimmer, E. A., Weigt, L. A., \& Janzen, D. H. (2005). Use of DNA barcodes to identify flowering plants. PNAS, 102(23), 8369-8374.

Kress, W. J., \& Erickson, D. L. (2007). A two-locus global DNA barcode for land plants: the coding $\mathrm{rbcL}$ gene complements the non-coding trnHpsbA spacer region. PLoS one, 2(6), e508.

Kurniawaty, N., Hidayat, P., \& Rauf, A. (2016). Characterization of Three Species of Thrips on Banyan, Nutmeg, and Marine Seruni Plants Based on COI Gene. Biosaintifika: Journal of Biology \& Biology Education, 8(2), 185-192.

Lahaye, R., Bank, M. V., Bogarin, D., Warner, J., \& Pupulin, F. (2008). DNA barcoding the floras of biodiversity hotspots. Proceedings of the $\mathrm{Na}$ tional Academy of Sciences, 105(8), 2923-2928.

Lambowitz, A. M. \& Zimmerly, S. (2004). Mobile group II introns. Annu Rev Genet, 38,1-35.

Madden T. (2013). The NCBI Handbook, 2nd edition. Bethesda (MD): National Center for Biotechnology Information (US).

Nugraha, F., Roslim, D. I., Ardila Y. P., \& Herman. (2014). Analisis sebagian sekuen gen ferritin2 pada padi (Oryza sativa L.) Indragiri Hilir Riau. Biosantifika: Journal of Biology and Biology Education, 6(2), 94-103.

Oyen, L. P. A. (2011). Elaeocarpus floribundus Blume. PROTA (Plant Resources of Tropical Africa). Netherlands. http://www.prota4u.org/search. asp. [20 Mar 2016].

Pang, X., Liu, C., Shi, L., Liu, R., Liang, D., Li, H., Cherny, S. S., \& Chen, S. (2012). Utility of the trnH-psbA intergenic spacer region and its combinations as plant DNA barcodes: A metaanalysis. PLoS ONE, 7(11), e48833.

Patwardhan, A., Ray, S., Roy, A. (2014). Molecular markers in phylogenetic studies- A Review. Journal of Phylogenetics \& Evolutionary Biology, 2,131 .

Pease, A. A., Davis, J. J., Edwards, M. S., \& Turner, T. F. (2006). Habitat and resource use by larval and juvenile fishes in an arid-land river (Rio Grande, New Mexico). Freshwater Biology, 51(3), 475-486.

Porebski, S., Bailey, L. G., \& Baum, B. R. (1997). Modification of a CTAB DNA extraction protocol for plants containing high polysaccharide and polyphenol components. Plant molecular biology reporter, 15(1), 8-15.

Price, P., Lovett, S. (2002). Managing Riparian Land. Fact Sheet 1. Land \& Water Australia, Canberra.

Rahman, S. S. \& Vacik, H. (2015). Identify appropriate conservation strategies for rural people in Ban- 
gladesh. Biodivers Manage Forestry, 4(1)

Raveendar, S., Lee, J., Jae-Wan, P., Gi-An, L., YoungAh, J., Yun, J. L., Gyu-Taek, C., Kyung-Ho, M., Sok-Young, L., Jong-Wook, C. (2015). Potential use of ITS2 and mat $K$ as a Two-Locus DNA Barcode for Identification of Vicia Species. Plant Breed Biotech, 3(1), 58-66.

Rosleine, D \& Suzuki, E. (2012). Secondary sucession at abandoned grazing sites, Pangandaran Nature Reserve, West Java, Indonesia. Tropics, 21(3), 91-103.

Roslim, D. I. (2016). Pandan (Pandanus sp), Rotan (Calamus sp), and Rengas (Gluta $\mathrm{sp}$ ) from Kajuik Lake, Riau Province, Indonesia. Brazilian Archives of Biology and Technology, 59(1), Bio1Appl. [in press]

Roslim, D. I., Nurkhairani, P., Herman, \& Elvyra, R. (2016a). Identification of Durik-Durik Plant (Syzygium sp) Using the psbA-trnH Intergenic Spacer and ITS Regions. TPGM, 3, 11-16.

Roslim, D. I., Herman, Sofyanti, N., Chaniago, M., Restiani, R., \& Novita, L. (2016b). Characteristics of 22 cassavas (Manihot esculenta L., Crantz) from Riau Province, Indonesia. $S A$ BRAO J Breed Genet., 48(2), 110-119.

Smith, M. A., Fisher, B. L., \& Hebert, P. D. N. (2005). DNA barcoding for effective biodiversity assessment of a hyperdiverse arthropod group: The ants of Madagascar. Philosophical Transactions of the Royal Society of London B: Biological Sciences, 360(1462), 1825-1834.

Snow, N., Young, S. L., Callmander, M. W. (2016) Syzygium dawsoniana (Myrtaceae): A New Species from New Caledonia with Bullate Leaves. Systematic Botany, 41(1), 197-201.
Tjitrosoepomo, G. 2003. Morfologi Tumbuhan. Yogyakarta: Gadjah Mada University Press.

Uddin, S. B. (2014). Medicinal plants of Bangladesh. Cell, 880, 1711065377

White, T. J., Bruns, T. D., Lee, S. B., \& Taylor, J. W. (1990). Amiplification and Direct Sequencing of Fungal Ribosomal RNA Genes for Phylogenetics. In: PCR Protocols and Application: A Guide to Methods and Applications. Academic Press, Inc.

Will, K. W. \& Rubinoff, D. (2004). Myth of the molecule: DNA barcodes for species cannot replace morphology for identification and classification. Cladistics, 20(1), 47-55.

Wojciechowski, M. F., Lavin, M., \& Sanderson, M. J. (2004). Phylogeny of legumes (Leguminosae) based on analysis of the plastid Matk gene resolves many well-supported subclades within the family. American Journal of Botany, 91(11), 1846-1862.

Yu, J., Xue, J. H., \& Zhou, S. L. (2011). New universal $m a t K$ primers for DNA barcoding angiosperms. Journal of Systematics and Evolution, 49(3), 176181.

Zeug, S. C. \& Winemiller, K. O. (2008). Relationships between hydrology, spatial heterogeneity, and fish recruitment dynamics in a temperate floodplain river. River Research and Applications, 24(1), 90-102.

Zoschke, R., Nakamurab, M., Lierea, K., Sugiurab, M., Börnera, T., \& Schmitz-Linnewebera, C. (2010). An organellar maturase associates with multiple group II introns. PNAS, 107(7), 32453250. 